\title{
中波ビーユンに重畳されたDGPS補正データ放送の受信
}

\author{
安田 明生 $*$ ・岡村 知則** \\ 浪江 宏宗***.川村 雅志*
}

\section{Reception of the DGPS Correction Data Broadcasting by MF Marine Radiobeacon}

\author{
Akio YASUDA, Tomonori OKAMURA, \\ Hiromune NAMIE and Masashi KAWAMURA
}

\begin{abstract}
The test transmission of DGPS correction data (Type-1 message at the moment, to be shifted to Type- 9 in the regular operation) in Japan has been carried out since December 1995 from MF beacon stations at Turugi-saki $\left(35^{\circ} 08^{\prime} \mathrm{N}, 139^{\circ} 41^{\prime} \mathrm{E}\right)$ and Daioh-saki $\left(34^{\circ} 16^{\prime} \mathrm{N}, 136^{\circ} 54^{\prime} \mathrm{E}\right)$. Their output power and the transmission rate are $130 \mathrm{~W}$ and 200 bps respectively. The cover area of the original mission of the radiobeacon is $200 \mathrm{~km}$. The reception rate in Tokyo and Sagami Bays, inside the circle of 50 $\mathrm{km}$ from Turugi-saki station, is observed to be more than $99 \%$ on 'Shiojimaru'. The maximum duration of the failed reception was 13.2s. It is short enough to obtain the accurate DGPS positioning.

The authors also tried to receive it on land in Tokyo urban area about $50 \mathrm{~km}$ away from Turugisaki station. The correction data are acquired on a running ordinary passenger car. A fairly well reception rate is available except on a way surrounded by tall buildings. Thus it would be applicable to the car navigation set, since it works well owing to the jointly used INS if correct positions are obtained even with the interval of several minutes.
\end{abstract}

\section{1.はじめに}

GPSは手軽に高精度の測位が可能なので、広く普及している。しかしながら、一般の利用者向けのサー ビスにはSA と呼ばれる精度劣化操作が施され、その精度は $2 \mathrm{drms} ゙$ 亿゙ $100 \mathrm{~m}$ 程度といわれており、高精度の測 位にはディファレンシャル運用が不可欠である。DGPSの擬似距離補正データは基準局から数百マイルの距 離でも有効(1)なので、これが放送されれば、多くのユーザーがその恩恵に浴する。

その手段としては、現行の放送波に重疊されることが多く、すでに欧米では、海上向け中波ビーコン波 にMSK変調により補正データを重畳して放送している(2)(3)。我が国でも海上保安庁により、同様のシステ 厶使って日本沿岸に分布する無線標識局から平成 8 年度以降、補正データ放送を順次開始す心゙く準備が進 められており (4)、平成 7 年12月から大王埼と剣埼の中波ビーユンにデータを重畳して実駼放送が開始された。 国内の無線標識局は $200 \mathrm{~km}$ 程度まで離れていても利用可能であるとされており、海上はもとより陸上での高 精度測位も可能となることが期待される。本稿では、東京商船大学の定点で剣埼からのビーコン電波によ る補正データの受信状況を観測すると共に、DGPS測位を行った結果について報告する。また汐路丸で東京 湾・相模湾を航行中及び、乗用車で東京都内、神奈川県内を走行中に補正データの受信を試みた状況につ

* 正 会 員 東京商船大学 情報通信工学研究室（テ135 東京都江東区越中島2-1-6)

** 非 会 員 東京商船大学 情報通信工学研究室（干135 東京都江東区越中島2-1-6）

***学生会員 東京商船大学 情報通信工学研究室（干135 東京都江東区越中島2-1-6） 
いて報告する。

\section{2. 送信局の諸元と補正データの内容}

平成 7 年 12 月、剣埼 $と 大$ 大埼の中波無線標識局 から発射される中波ビーコン電波にDGPS補正デー 夕を重畳して実験放送が開始された。剱崎の送信 鉄塔は東経139度41分、北緯35度8分に位置し、周

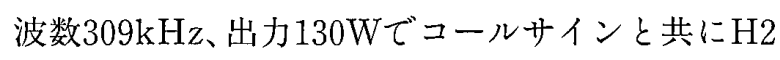
Aで連続的に送信している。一方、大王埼の送信鉄 塔は東経 136 度 54.2 分、北緯 34 度 16.5 分にあり、288 $\mathrm{kHz}$ でビーコン電波と同時に船舶気象通報を実施 している。平成 8 年5月中的現在、これらにMSK 変調で、RTCMフォーマットのDGPS補正データ の中、タイプ1メッセージを情報伝送速度200bpsで 送信していた。これについてはすでに多くの解説 がなされている。ここでは伝送という立場で簡単 に紹介する。DGPS補正データは30ビットを1ワー ドとして (最後の 6 ビットはパリティー)、DGPS 基準局としての局のID番号や正時毎にリ七ットさ れる0.6秒単位のデータ更新時刻 (Modified ZCount）などを2ワードヘッダとしてまず送信し、 以下 5 ワード每に3衛星の擬似距離補正值とその変 化率を送信する。後述の「3。実験結果」におけ る受信データの時間間隔は 2 ワードヘッダに表示 されるデータ更新時間による。図 1 に東京商船大 学で観測された剱埼局からの電波をスペクトルア ナライザ $(\mathrm{HP}-8562 \mathrm{~A})$ で観測したスペクトルを 示す。左側のピークの中心周波数は309kHzで、これが搬送波の部分に相当する。ピークょりー20dBの帯域 幅は $400 \mathrm{~Hz}$ 以下で、MSK変調特有の狭帯域幅化が実現していることが分かる。右側のピークはビーユン局 としての局識別符号送信時にのみ発生する上側波帯で、ピークの周波数間隔から700kHzの副搬送波により 変調されていることがわかる。この図では分からないが、左側にはピークはなく、単側波帯通信である。 データ量は衛星数に依存し、6衛星で12ワード、9衛星となる。まな、17ワードとなる。また、データの更 新時間間隔はこのデータ量に依存する。表にに衛星数に対するデータビット数、伝送所要時間を示す。タイ プ9は低品質回線用でRTCMで指定された伝送形式で3衛星分のデータ每に区切って送信される。表中衛星 数 1〜3 がこの場合で、例えば7衛星なら3-3-1機の順に、また8衛星なら 3-3-2機の順に衛星の補正データ

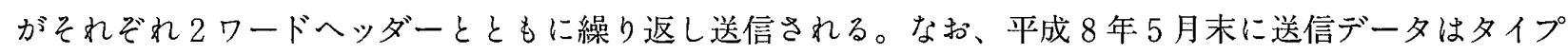
9 に切り換えられた。

\section{3. 実験結果}

表 2 に実験に用いた中波ビーユン受信機、光電製作所製KBR-900主要諸元を示す。付属のホイップアン

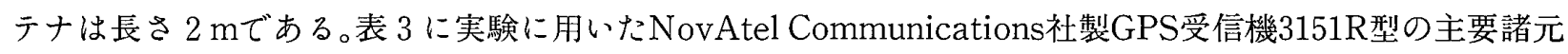
を示す。ビーュン受信機はRTCM形式のデータを正しく受信できたとき、“8の6"形式のデータに变換し て出力する。(データ中1ワードでもエラーが発生するときはそのデータは出力されない。GPS受信機はこ れを入力することにより、DGPS測位を実行する。図 2 に送信局と受信地点の位置関係を示す。図中に㰸埼 を中心とする半径 $50 \mathrm{~km}$ の在示す。 
3.1 東京商船大学における受信状況

剱埼ビーコン局から陸上で直線距離約 $60 \mathrm{~km}$ の東京 商船大学屋上にGPSアンテナ 2 台とビーコン受信機 アンテナを設置し、2台のGPS受信機でそれぞれ、 同時に単独測位とDGPS測位を行った。図 3 に 1 時間 にわたる 1 秒每の単独測位結果を、図 4 に剣埼ビー コン局の補正データを用いて同時に収集した 1 秒毎 1 時間にわたるDGPS测位結果を示す。単独測位にお

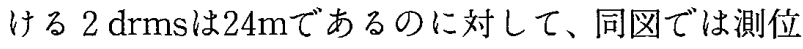
点の95\%を含む誤差楕円より大きく外れた点がいく つか見られるが、2 drmsは $1.4 \mathrm{~m}$ と大幅に精度が向上 しており、満足なDGPS測位が行われていると考えら れる。図 5 にこの間の衛星の配置を示す。测定開始 から12分間は 6 衛星、その後21番衛星が加わり 7 衛 星になり、さらに開始35分後には27番衛星が加わり 8 衛星となった。図 6 は図 4 の同時間内の経度方向、 緯度方向の測位結果の経時変化を示す。図 7 はこの 間のデータ受信状洗を示し、時間軸は図 6 と対応し ている。罒中のワード受信率は各ワードに付された パリティを調心、正しく受信出来たワード数の 1 分 当たりの割合を示す。 1 分間の伝送ビット数は 12,000 ビットなので、400ワード中の割合であり、平均で 87 \%の受信率が得られている。一方、データ受信率は タイプ1メッセージ中のすべてのワードが正しく受 信されたものの 1 分間の割合である。6 衛星で33.3 データ、7 衛星で28.6データ、8 衛星で 25.0 データ 中の割合で、平均では約 $45 \%$ である。改善後のデー タ受信率はデータ中にパリティエラーの発生したワ ードを含んではいるが、いくつかの衛星の補正デー タは利用可能であるものを正受信データ数に加えた ものの 1 分間の割合である。図 8 は正しく受信され たデータに付されたデータ更新時刻の時間間隔の密 度分布を示している。約 5 秒までのものはほとんぼ 連続的に正しく受信されているが、例えば20秒の間 隔で受信できたものはそれまでに数個のデータが受 信できなかったことになる。図 7 において経過時間 49分の所で受信率が大きく低下しているが、図 6 からこの時間に特に精度が劣化しているようにも見えな い。20 30秒程度の伝送遅延では一般的にほとんぼ測位精度の劣化は無い(5)ので、この時間帯では伝送遅延 による精度劣化は現れていないと考えられる。図 9 はこの時間帯ではないが、伝送遅延により測位精度が 劣化した例を示す。知印で示した時間のデータが正しく受信されたことを示す。知印の上下方向は特に意 味がない最大 28.8 秒のデータの連続不受信では測位值は徐々にドリフトし、データ受信と共に0 付近に 戻っている様子が示されている。これはSAによる擬似距離変化率が特に大きい場合である。このときの受 信実験では受信機の接地が不十分であったなめS／Nが低く、受信率も良くなかったようである。その後接 地を改良した結果、90\%以上のデータ受信率が得られた。

3.2 海上（東京湾・相模湾）に拈ける受信状況

海上での受信実験は本学練習船「汐路丸」のコンパスデッキ左舷側のハンドレール上に、受信機付属の 長さ約 $2 \mathrm{~m}$ のアンテナを設置し、東京湾と相模湾でデータを収集した。館山沖から伊東沖の相模湾で操船実 


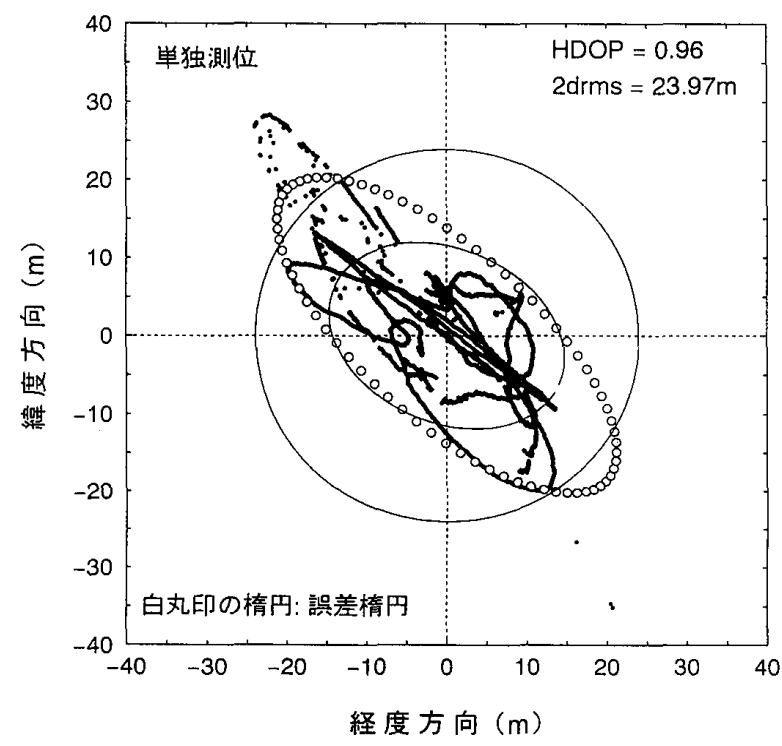

図3定点に和ける単独測位分布

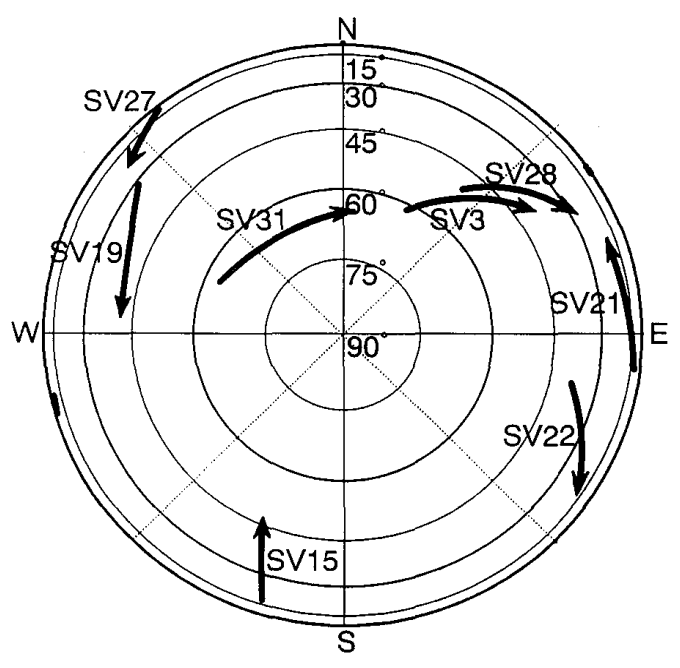

困 5 衛星配置の地平面図

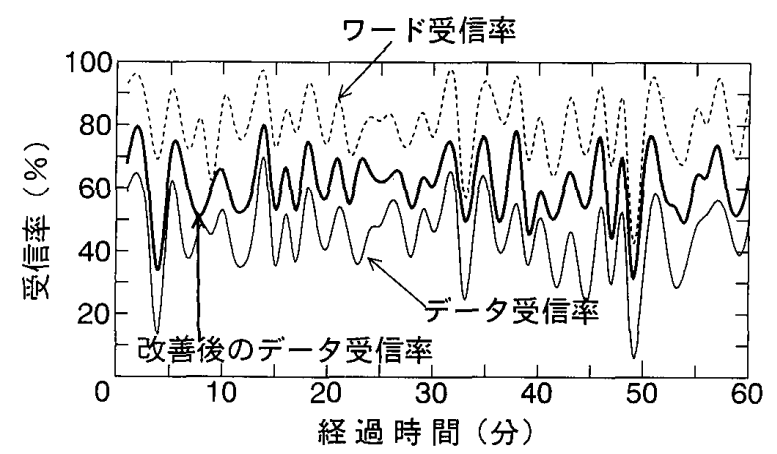

园 7 定点における 1 分ごとのワード受 信率とデータ受信率の経時変化

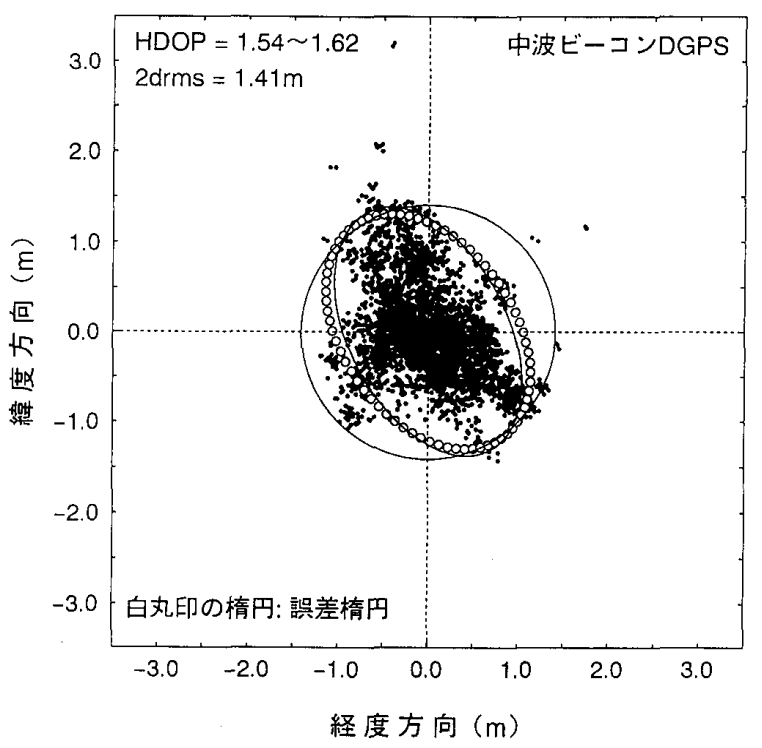

図4定点におけるDGPS測位分布
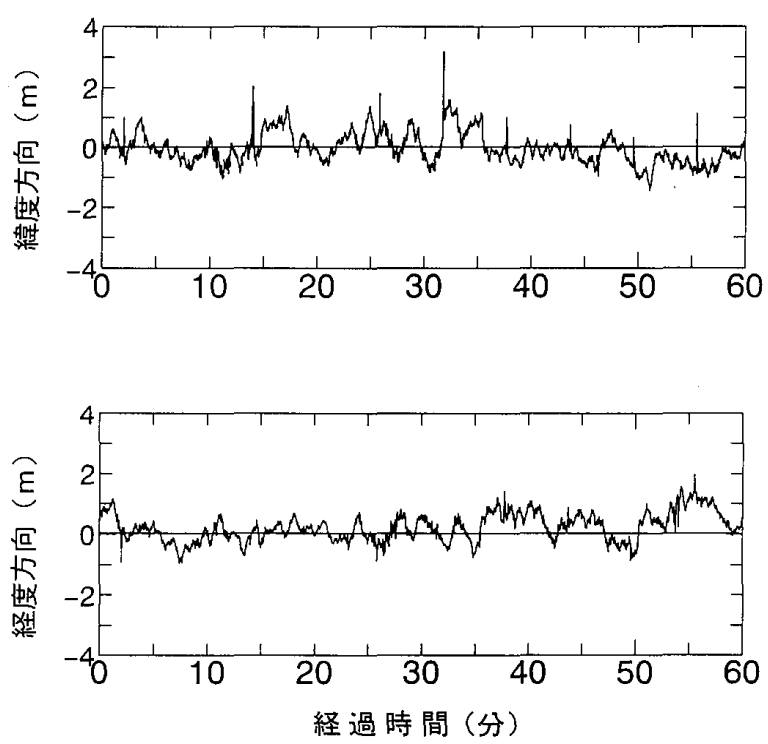

図 6 定点のDGPS測位における緯度方 向、経度方向の測位値の経時変化

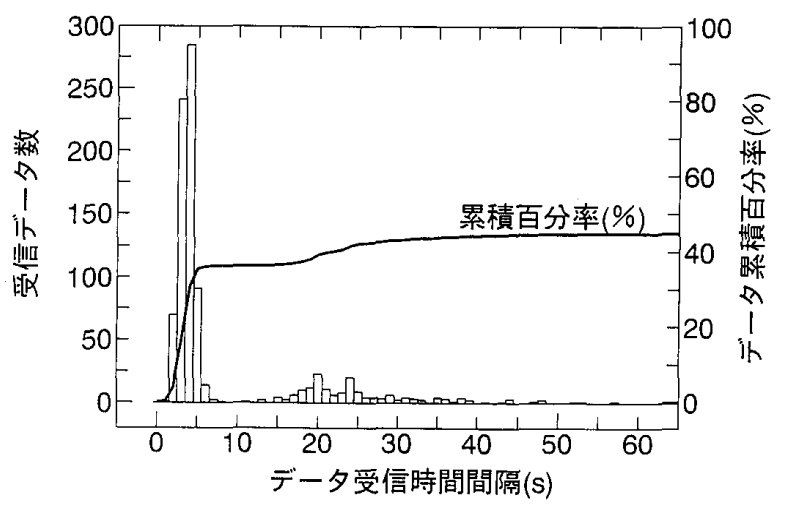

图 8 定点における受信データの更新時 間間隔毎のデータ数と密度分布 
験中の約 4.5 時間のデータでは約 16,000 個のうち50個 が受信できなかったが、この間のデータの最大受信 時間間隔は13.2秒で、测位にほとんぼ影響を与えな い。また伊東沖から東京月島の係船地までの約5時間 では約18,000個中、39個の久足にとぼまった。これ らのことから、DGPSが効力を発揮する陸岸沿いの航 海や入港あるいは港湾内での航行には十分に効果を 発揮するものと考えられる。

3.3 市街地における受信状況

一方、陸上での利用可能性を探るために、乗用車 にアンテナを設置し走行中の受信を試みな。表 4 に 日中東京敵船大学付近の市街地を走行中の 10 分間の 受信状況を示す。正門で左折し、清澄通りる南下し、 晴海通りで左折し、ホテル浦島前の交差点を左折し、 豊洲まで走行したときのもので、片側 2 車線以上の 比較的周囲の開けた道路である。送信データ総数は 285個、データ長は14ワードで7衛星の補正データを 持っている。(1)は正しく受信できたデータ数を受信 間隔ごとに集計したものである。(2)はへッダは正し く受信できたデータ数でエラーが1ワード以上発生し たもの55個を含む。このうち32個は1２衛星のデー タが落しているだけである。間隔3秒以下は中断な く連続して受信できたものの数を示す。

図10は東京商船大学から東京駅、皇居前、国会議 事堂を経て、新宿高層ビル街、さらに高田馬場、池 袋、早稲田、駒込、秋葉原を経て大学までの都内市 街地を走行中のデータ受信状況で、高田馬場、駒込、 秋葉原付近では片側 1 車線の狭い道路が多く最大で 18分間もデータ受信率 0 が続いた。一方図11は横浜 方面から国道 1 号線を東京方面に向かったもので、 神奈川県内では平均して70\%以上のデータ受信率が 得られている。

最近のカーナビは、INSと併用されることが多く、 数分毎にでも正確な位置が得られれば良いといわれ ているので、市街地でも十分にその機能を果たし得 ると考えられる。

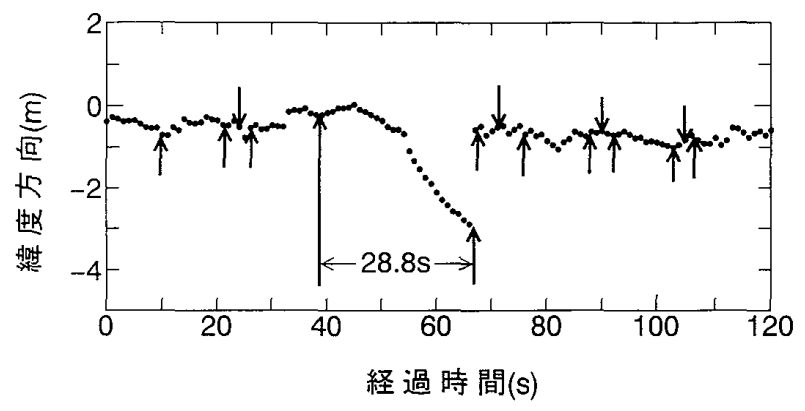

図 9 受信データ間隔と測位值変動の一例

表 4 東京商船大学付近走行中の受信状況(デー夕総数285)

\begin{tabular}{|c|c|c|c|}
\hline 更新間隔 & $3 \mathrm{~s}$ 以下 & $3 \mathrm{~s} \sim 20 \mathrm{~s}$ & Times over $20 \mathrm{~s}$ \\
\hline$(1)$ & 136 & 22 & $(34 \mathrm{~s})(37 \mathrm{~s})(70 \mathrm{~s})$ \\
\hline$(2)$ & 204 & 10 & $(28 \mathrm{~s})(68 \mathrm{~s})$ \\
\hline
\end{tabular}

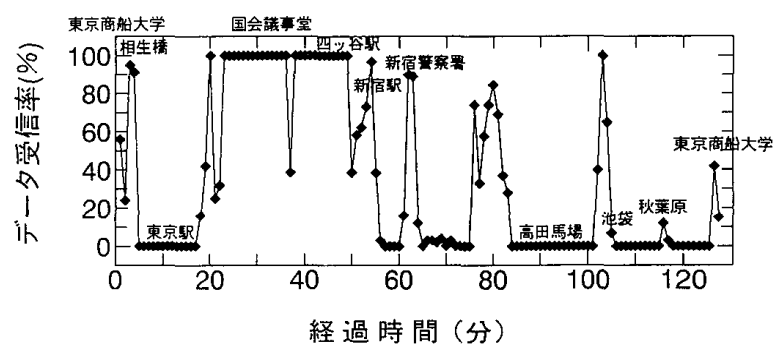

図10 東京都内市街地走行中に执ける受信状況

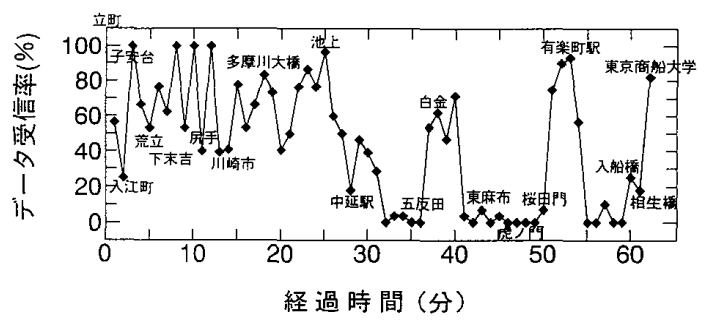

図11 横浜市から東京商船大学までの市 街地走行中における受信状況

\section{4.あとがき}

我が国においても、海上保安庁により航行の安全のために、剣埼と大王埼の中波ビーコン局でDGPS補正 データ放送の実験放送が開始された。本研究においてはこの有効性を確かめるために、剱埼局から直線距 離で陸上約 $60 \mathrm{~km}$ 離れた東京商船大学の定点および東京湾・相模湾を航行中の船舶上と東京都内・神奈川県 内走行中の乗用車で受信状況を調べた。その結果定点ではデータ受信率は50\%以下であったが、十分に高 精度のDGPS測位が可能であることが示された。また、東京湾・相模湾では送信局に近いということもあっ てほぼ100\%のデータ受信率が得られ、特にDGPSが効力を発揮するであろう陸岸沿いの航海や入港あるい は港湾内での航行には十分にその効果を期待できることがわかった。一方、乗用車での受信では神奈川県 内では高い受信率を得ることができたが、東京都内では高層ビルの間の道路で十数分間にわたってデータ 
の受信ができないという場合もあった。しかしながら、陸上での応用の中心であるカーナビではINSと併用 されるので、数分毎にでも正確な位置が入れば十分であるといわれているので、基準局からの距離が近け れば十分に活用できると考えられる。中波ビーコンによる補正データ放送は無料で提供されるので、今後 本放送への移行および全国への展開とともに多くの新なな活用が期待される。

平成 8 年 6 月現在、データ形式はタイプ 9 に切り替わっている。この場合 1 データ当たりのワード数は 最大で 7 なので、データ受信率はさらに良くなるであろう。東京湾・相模湾での受信に関しては全く関係 ないものの、車での受信では受信状況の改善が期待される。今回は移動しながらの測位の評価は行わなか ったが、改善されるはずのデータ受信率の測定と同時に、測位の評価も試みたいと考えている。

\section{謝 辞}

「航行測位衛星システムを使った測位の位置誤差補正に関する調査研究委員会」(財団法人日本航路標識協 会)の木村小一委員長はじめ委員の皆様方にDGPSに関し広くご討議頂きました。また、光電製作所、藤野 輝久、前田久昭の両氏には、受信機をご貸与頂くとともにデータ処理に関しご教示頂きました。ここに、 謝意を表しま寸。

\section{参 考 文 献}

（1）柿原利治・武田誠一・宮本佳則・野田 明・峰 雄二：基準局・移動局間距離 $と$ DGPS測位精度につい て，日本航海学会論文集第93号，pp.1-6，1995年9月.

(2) Lt.M.Lunday,J.Spalding and M.Dowd : Verification of USCG DGPS Broadcast Parameter, Proceeding of ION GPS-95, pp.889-897, Sept.1995.

(3) P. Enge, P. Levin, A. Hansen and R. Kalafus: : Covarage of DGPS/Radiobeacons', Navigation, J.of ION,Vol.39, No.4, pp.363-381, winter 1992-1993

（4）塩山寿男・西田之重：ディファレンシャルGＰＳの動向について，日本航海学会誌，第125号，pp.4653 , 平成 7 年 9 月.

（5）安田明生・俞 豊・浪江宏宗：DGPSのデータ伝送遅延に対する測位精度評価，日本航海学会論文集第 93 号, pp.7-10, 平成 7 年 9 月.

\section{質 疑 応 答}

新井康夫(海技大学校)：(1) データ受信率が悪くなる原因について、S/Nやマルチパスの影響が考えられ るが、今回の実験で検討されたでしょうか。

(2) 定点位置でデータ受信率が50\%であっても精度が $1.5 \mathrm{~m} （ 2 \sigma)$ であったとのことですが、移動体で はもっと精度が悪くなるのではないでしょうか。

安田明生：(1) 中波の場合、S/Nはフェーディング（マルチパス）による信号の強弱 $(\mathrm{S})$ と周囲雑音 $(\mathrm{N})$

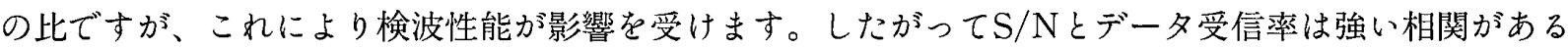
と思いますが、今回は測定していません。

（2）移動体の場合は周囲の状況によって使用できる衛星数が制限されたり、干涉により測距精度が悪く なる場合があるので、一般的に測位精度が悪くなると思います。データ受信率が良いか悪いかは定点で あるかどうかとは無関係のように思います。 